\title{
Zika virus: what do we know about the viral structure, mechanisms of transmission, and neurological outcomes?
}

\author{
Lucia Regina Cangussu da Silva ${ }^{[1]}$ and Adriano Miranda de Souza ${ }^{[2]}$
}

[1]. Departamento de Ciências Biomédicas, Universidade Salgado de Oliveira, Juiz de Fora, Minas Gerais, Brasil.

[2]. Departamento de Farmacologia, Universidade Federal de Juiz de Fora, Juiz de Fora, Minas Gerais, Brasil.

\begin{abstract}
The Zika virus epidemic that started in Brazil in 2014 has spread to $>30$ countries and territories in Latin America, leading to a rapid rise in the incidence of microcephalic newborns and adults with neurological complications. At the beginning of the outbreak, little was known about Zika virus morphology, genome structure, modes of transmission, and its potential to cause neurological malformations and disorders. With the advancement of basic science, discoveries of the mechanisms of strain variability, viral transfer to the fetus, and neurovirulence were published. These will certainly lead to the development of strategies to block vertical viral transmission, neuronal invasion, and pathogenesis in the near future. This paper reviews the current literature on Zika virus infections, with the aim of gaining a holistic insight into their etiology and pathogenesis. We discuss Zika virus history and epidemiology in Brazil, viral structure and taxonomy, old and newly identified transmission modes, and neurological consequences of infection.
\end{abstract}

Keywords: Zika virus. Transmission modes. Microcephaly. Guillain-Barre syndrome. Neurological disorders.

\section{INTRODUCTION}

Recently, scientific knowledge on the structure and mechanisms of transmission of Zika virus as well as on neurological malformations and disorders caused by its infection has been rapidly advancing, in great part because of joint efforts of Brazilian scientists. Circulation of the virus was first confirmed in March 2015 in Brazilian patients in Camaçari, State of Bahia ${ }^{(1)}$. The viral strain proved to be genetically similar (99\%) to a French Polynesian isolate, leading to the assumption that it was brought to Brazil by infected tourists who came as spectators to the World Soccer Cup in June/July 2014(2) (3). By the end of March the following year, a laboratory-confirmed case of Zika virus infection was reported in a male Italian tourist who had been to Salvador, Bahia, confirming circulation of the virus in our country ${ }^{(4)}$.

Zika virus has spread all over the country, causing thousands of infections ${ }^{(5)}$. These infections have not been precisely quantified owing to a lack of prompt testing of symptomatic patients, and because most infected patients are asymptomatic( ${ }^{(6)}$. In addition, the disease was not included in the national notifiable disease list until February 2016. This paper reviews the current viral epidemic in Brazil and key scientific advances that have increased our understanding of Zika virus and the disease.

Corresponding author: Profa. Lucia Regina Cangussu da Silva. e-mail: Prof.luciacangussu@gmail.com

Received 16 May 2016

Accepted 14 June 2016

\section{History and epidemiology of Zika virus in Brazil}

Zika virus, of the Flaviviridae family, is the most recent arbovirus circulating in Brazil. It has been known as an infectious agent since 1952 when a rhesus macaque developed fever in the Zika Forest in Uganda, Africa ${ }^{(7)}$. Since 1954, sporadic cases of infection have been reported on the African and Asian continents ${ }^{(8)}$. The first large Zika virus epidemic was reported in the Yap Island, Micronesia, in 2007, when it was estimated that $73 \%$ of the population was exposed to the virus and developed rash, conjunctivitis, and arthralgia ${ }^{(9)}$. By the end of 2013, the same strain had disseminated to the French Polynesia islands ${ }^{(10)}(11)$, infecting $\sim 11 \%$ of the population and reaching the East Island, located only $3,700 \mathrm{~km}$ from the coast of Chile, in 2014 ${ }^{(12)}$. Sporadic cases of Zika virus infection in tourists returning from areas affected by the epidemic have been reported in many countries where the Aedes mosquito vector species are not present ${ }^{(13)(14)(15)(16)(17)(18)}$.

In Brazil, Zika virus ribonucleic acid (RNA) was detected in March 2015 in blood samples from patients presenting denguelike symptoms. This confirmed that the virus had spread from Bahia to Natal, Rio Grande do Norte ${ }^{(2)}$, and prompted the Pan American Health Organization (PAHO) to launch an alert in countries in the Americas to develop technical capability to detect and confirm Zika fever cases $^{(7)}$.

Brazil was the first country to report laboratory-confirmed deaths caused by Zika virus ${ }^{(19)}$. It was initially hypothesized that the causative virus strain had mutated and had become more virulent, since microcephaly was also being reported. It is well 
established that mutations in the gene that encodes the viral envelope glycoprotein E of other members of the Flaviviridae family increase their virulence and their ability to damage the central nervous system ${ }^{(20)}$.

Zika virus infection has now become an emerging infectious disease, with local transmission detected in $>30$ countries or territories ${ }^{(21)}$. Evidence of vertical Zika virus transmission in Brazil comes from blood and tissue samples obtained from a microcephalic newborn in October $2015^{(22)}$. Brazil reported an alarming figure of 7,438 suspected microcephaly cases by the $18^{\text {th }}$ epidemiological week $2016 ; 1,326$ of these cases were confirmed as congenital infection ${ }^{(23)}$. Most microcephaly cases $(5,706)$ have been reported in the Northeast region of Brazil, suggesting the possibility of other interfering factors, such as infectious agents, environmental and genetic factors, that lead to the development of microcephaly. During the French Polynesian outbreak, only eight microcephaly cases were retrospectively identified and the estimated risk calculated as 95 per 10,000 infected women in the first trimester of pregnancy ${ }^{(24)}$. Therefore, we cannot rule out other causes of microcephaly in Brazil.

\section{Taxonomy and structure of the Zika virus particle}

Zika virus has been classified as a member of the family Flaviviridae, genus Flavivirus(25). Most viruses from this family are transmitted by mosquito or tick bites causing mild to potentially lethal infections in humans, the latter resulting from myelitis, encephalitis, and hemorragia reported for yellow fever, dengue, West Nile fever, Japanese encephalitis, and others $^{(26)(27)(28)}$.

The Zika virus particle has the same general structure as other Flavivirus species ${ }^{(29)}$. It is spherical, $42-52 \mathrm{~nm}$ in diameter ${ }^{(30)}$. Its envelope is formed by a lipid bilayer embedded in 180 units of glycoproteins $\mathrm{E}$ and $\mathrm{M}$ for binding to a variety of cell receptors ${ }^{(31)}$. Glycoprotein $\mathrm{E}$ has a typical three-domain structure, but differs from that of dengue-2 virus because it has only one glycosylation site (Asn154) that appears as a small protrusion on the viral surface. Glycosylation at this specific site has been linked to neurotropism of the West Nile virus ${ }^{(32)}$. Notably, loss of glycosylation sites has been noticed in Zika virus strains from Africa that are not commonly reported to cause neurological damage. Glycosylation has been reported in Asian strains causing Guillain-Barre syndrome (GBS) and microcephaly, as seen in Brazil ${ }^{(33)}$. In another study, the loss and gain of glycosylation sites detected in African strains were associated with viral capacity to infect specific mosquito species $^{(34)}$.

Zika virus nucleocapsid is formed by protein $\mathrm{C}$ associated with a positive-sense, single-stranded viral RNA molecule ${ }^{(29)}$ that has a genomic organization characteristic of the Flaviviridae family, encoding three structural and seven non-structural proteins $^{(35)}$. A complete genome sequencing of the Brazilian strain verified that it shared $97-100 \%$ similarity with the French Polynesian strain, with $51.2 \% \mathrm{GC}$ ratio $^{(36)}$. In contrast to what was initially hypothesized, no recombination events were detected that would explain its enhanced neuroinvasion or neuropathogenesis. Similar results were obtained for Zika virus isolate that infected a Slovenian woman in $\mathrm{Brazil}^{(30)}$. The long viral persistence in the mother and fetus, from $13^{\text {th }}$ to $32^{\text {nd }}$ week of pregnancy, deserves attention and has been reported in other Zika microcephaly cases ${ }^{(37)}$. The virus replicates in the rough endoplasmic reticulum membranes, as demonstrated in brain cells in vivo ${ }^{(30)(37)}$ and in neurospheres in vitro ${ }^{(38)}$.

\section{Zika virus: old and newly identified transmission modes}

It has been assumed in the past that Zika virus was solely transmitted by bites of mosquitos from the genus Aedes (subgenus Stegomyia). This notion was questioned as other modes of transmission were identified. Many species of the genus Aedes can spread the virus in different geographic regions in natural and urban environments ${ }^{(33)(34)(39)(40)(41)}$, however, their potential as vectors is variable and only $20-50 \%$ of infected females carry virus particles in the saliva in some species ${ }^{(42)(43)}$.

Saliva and urine are now accepted as vehicles for Zika virus transmission, since viable Zika virus particles were isolated from the saliva and urine of two acute-phase patients in Brazil. The virus was cultured in Vero cells, inducing typical cytopathic effects and raising the possibility of transmission from an infected patient to a non-immune human host ${ }^{(44)}$. Interestingly, an earlier report exists of Zika virus transmission by a monkey bite in an Australian tourist returning from Indonesia, which was dismissed as improbable at the time ${ }^{(45)}$.

The presence of viable Zika virus particles in the blood bags can have serious consequences, especially for pregnant women. Other viable Flavivirus viruses in the blood bags have also been reported ${ }^{(46)(47)(48)}$. Simultaneous circulation of two or more arboviruses ${ }^{(43)}$ in many countries highlights the necessity for proper screening of blood samples for these viruses. Genetic material of three different viruses has been detected in samples from a single patient in Latin America ${ }^{(39)}\left({ }^{(49)}\right.$ and Zika virus RNA and viable particles were detected in blood samples from asymptomatic donors in French Polynesia ${ }^{(50)}$. In Brazil, viral RNA was detected in a patient who received blood transfusion from an asymptomatic donor who developed the disease a few days later ${ }^{(51)}$. The Brazilian Health Surveillance Agency [Agência Nacional de Vigilância Sanitária (ANVISA)] recommended that blood donors with laboratory- or clinicallyconfirmed Zika virus infections should be ineligible for blood donations for 30 days following complete clinical recovery, and that blood banks should be notified if the donors develop any symptoms a week after donation ${ }^{(52)}$. Ultraviolet light and amotosalen have been proposed as an efficient method of inactivating arboviruses in the blood samples ${ }^{(53)}$.

Zika virus can also be sexually transmitted. The initial evidence came from two male American researchers who went to an endemic area in Senegal to collect mosquito samples ${ }^{(54)}$. One of them reported hematospermia and his wife, who had not left their place of residence (Colorado), presented arthralgia, exanthema, and oral ulcer, similar to her husband. Anti-Zika virus and anti-yellow fever antibody titers were high in both men, but the attempts to culture the virus in human or Aedes cells 
were unsuccessful. One can assume that during the acute and viremic phase of infection, the damage to vascular endothelium results in blood cell and Zika virus particle shedding into the semen, favoring transmission.

High copy numbers of Zika virus RNA $\left(2.9 \times 10^{7} / \mathrm{mL}\right)$ was detected in the semen of a patient with prolonged Zika virus infection and the load remained high $\left(1.1 \times 10^{7} / \mathrm{mL}\right) 6$ days later. Urine and semen cultures were positive ${ }^{(55)}$, confirming that these fluids can constitute viral routes of infecting a new host. Viral load in the semen was $100,000 \times$ higher than in the serum or urine, which can be explained by the immune privilege of male reproductive organs ${ }^{(56)}$. Viral RNA has been detected in the semen up to 62 days after the onset of illness, making sexual transmission a serious concern unless condom use is encouraged ${ }^{(57)}$.

Vertical transmission of the Zika virus has become a serious risk to pregnancy and fetal development, leading the World Health Organization (WHO) to consider the disease a Public Health Emergency of International Concern (PHEIC) ${ }^{(58)}$. One of the first reports, published by Besnard and co-workers ${ }^{(59)}$, described two cases of perinatal transmission of the virus in French Polynesia. Viral RNA was detected in the blood, saliva, and urine samples from mothers and newborns, as well as in breast milk (up to $250 \times 10^{4}$ copies of $\mathrm{RNA} / \mathrm{mL}$ ) from both mothers, but breast milk cultures were negative. Clearance of the virus from the plasma and urine of mothers and newborns by the $11^{\text {th }}$ day post-delivery suggested an effective immune response to infection.

Doubts concerning the safety of breast feeding by mothers infected with Zika virus were also raised when a woman with 35,000 copies of Zika virus RNA $/ \mathrm{mL}$ in the blood on day 3 postdelivery was found shedding 850,000 copies $/ \mathrm{mL}$ of breast milk on day 4 . The particles replicated in Vero cell culture, reaching $30,000,000$ copies $/ \mathrm{mL}$. Results from the newborn blood sample were ambiguous and it is not clear whether the child developed the disease ${ }^{(60)}$.

The first convincing evidence of vertical transmission came after the detection of Zika virus RNA and proteins in a preserved microcephalic fetus of a Brazilian woman at $8^{\text {th }}$ week of gestation. Viral proteins were found inside macrophages ${ }^{(61)}$ abundant in the chorionic villi ${ }^{(62)}$. One could easily postulate that these innate immune mobile cells were acting as Trojan horses, carrying the virus from the mother to her fetus ${ }^{(63)}$. Zika virus proteins were also detected in the chorionic villi in one case of miscarriage in Brazil ${ }^{(64)}$. These results confirmed that the virus reached the placental tissue in infected pregnant women.

An irrefutable proof of vertical transmission came after Zika virus RNA was detected in the amniotic fluid collected by amniocentesis and incomplete and complete viral particles were detected in the brain cells of an aborted fetus. This proved that the virus passed through the placental barrier, with the potential to infect fetal neural cells, replicate, and induce neurological damage ${ }^{(30)(36)}$. Diagnosis of microcephaly and other neurological malformations in a fetus after 16 weeks of Zika infection symptons manifestations in the mother revealed that Zika virus persists in pregnant women and in their fetuses, infecting and damaging brain cells during neurogenesis ${ }^{(36)}$.
Viral RNA was also found in brain tissues of two newborns, who unfortunately did not survive long after birth, in Brazil. Viral antigens were detected in mononuclear cells in the brain tissue of one of these newborns, a possible outcome of viral invasion of the host immune cells ${ }^{(64)}$. Although these studies confirmed neurotropism of the Zika virus once it has passed through the placental barrier during pregnancy, they did not explain how the virus damages the neural cells.

\section{Neurological outcomes associated with Zika virus infections in fetuses, newborns, and adults}

It is well established that several members of the Flaviviridae family can cause serious neurological damage through neuroinvasion and neurovirulence ${ }^{(20)}$. The Japanese encephalitis virus (JEV) alone causes $>67,000$ infections annually in 24 countries, with $20-30 \%$ lethality and $30-50 \%$ of psychiatric and other neurological sequelae ${ }^{(65)}$. The recent rise in reports of microcephaly and other neurological complications associated with Zika virus infections in Brazil has led to a rapid increase in scientific collaborations ${ }^{(58)(66)}$ to elucidate the mechanisms of viral pathogenesis and immune response. A summary of these efforts is presented below.

\section{Zika virus and microcephaly}

Microcephaly is by far the most serious and irreversible neurological complication caused by Zika virus infection ${ }^{(36)}$. It is characterized by a reduction in the cephalic perimeter, usually caused by an inappropriate development and/or destruction of the neural cells. It can be detected by ultrasound, tomography, or by cephalic perimeter measurements. According to WHO, newborns with a head circumference $>2$ standard deviations below the expected mean should be considered as having microcephaly, and those with $>3$ standard deviations below the expected mean should be considered as having severe microcephaly ${ }^{(67)}$.

Congenital Zika virus infection presents most commonly as microencephaly, ventriculomegalia, and intracranial calcifications. Hydranencephaly, intracranial calcifications, destructive lesions of the posterior fossa, hydrothorax, ascites, subcutaneous edema, and arthrogryposis have been described in severe cases $^{(68)(69)}$. It is important to rule out other infectious agents that are known to induce microcephaly ${ }^{(38)(70)}$ before ascribing it to Zika virus infection.

Ocular lesions have been observed in $34.5 \%$ of microcephalic newborns ${ }^{(71)}$ and can be extensive, with macular atrophy, optical nerve alterations, optic disc hypoplasia, gross macular pigment mottling, and juxtafoveal chorioretinal atrophic lesions ${ }^{(71)}(72)$. Most of the reports, however, have been published at the beginning of the Brazilian outbreak and additional detailed studies are needed to establish a link between Zika virus and ocular lesions.

Placental structure and function seem to be preserved during Zika virus infection ${ }^{(64)}$, since the reduction in newborn size and trophoblastic invasion and preterm deliveries are not so frequent ${ }^{(73)}$. Furthermore, normal blood flow from the mother to the fetus was observed despite focal calcifications in villi and 
decidua ${ }^{(30)}$. In one case of miscarriage, heterogeneous chorionic villi calcification, fibrosis, perivillous fibrin deposition, patchy intervillositis, and focal villitis were noted ${ }^{(64)}$.

Analyses of tissue samples from a microcephalic aborted fetus provided detailed information at the macroscopic, histological, and immunocytochemical levels about neurological damage induced by a congenital infection with Zika virus ${ }^{(30)}$. Microencephaly (84g), widely open sylvian fissures, small cerebellum and brain stem, almost complete agyria, internal hydrocephalus of the lateral ventricles, numerous variablysized calcifications in the cortical and subcortical white matter, autolysis, and cortical displacement were reported, revealing profound anatomical modifications. Clusters of dense virus-like particles seen in damaged cytoplasmic vesicles showed that the virus was capable of replication in fetal neurons, as was later confirmed by Brazilian in vitro studies with neurospheres ${ }^{(38)}$.

Similarly, a study by Maklar and co-workers ${ }^{(30)}$ demonstrated the strong neurotropism of Zika virus, as viral RNA was detected in the brain tissue $\left(6.5 \times 10^{7}\right.$ copies $\left./ \mathrm{mg}\right)$ but not in any other fetal organ. Similar results were obtained in a study involving two miscarriages and two microcephalic newborns in Brazil, with histopathological changes limited to the brain and including parenchymal calcification, microglial nodules, gliosis, cell degeneration, and necrosis ${ }^{(64)}$.

The neuropathological mechanisms associated with Zika virus infections seem to involve cellular invasion, alteration of the expression of $>500$ host genes, impairment of the ability of neural progenitor cells to differentiate into neurons, and induction of caspase-mediated neural progenitor cell death ${ }^{(74)}$. These phenomena, associated with the presence of activated microglial cells and macrophages in most of the cerebral gray and white matter, and mild perivascular infiltrates composed of $\mathrm{T}$ cells and some B cells, indicate immunological involvement in tissue damage ${ }^{(30)}$. Recruitment of macrophages expressing the scavenger receptor CD60 contributes to the removal of cellular debris ${ }^{(37)(74)}$. Neurogenesis would be impaired by viral aggression and immune activation, explaining, at least in part, the drastic reduction in the bulk of the central nervous system in microcephalic fetuses and newborns.

\section{Zika virus, GBS, and other neurological disorders in adults}

Guillain-Barre syndrome is an acute auto-immune polyradiculoneuropathy that may be caused by infections, many of which involve Flavivirus ${ }^{(27)}$ and other arboviruses such as Chikungunya ${ }^{(75)}$. It is characterized by superior/ inferior limb extremity paresthesia, ascending muscular weakness, and paralysis that can evolve into respiratory and deglutition disorders, and death ${ }^{(76)}$. The sensorimotor deficits are symmetrical and bilateral. GBS immunopathogenesis is complex, involving Toll-like receptors, production of pro-inflammatory cytokines with mielinotoxic activity, cellmediated immune responses with cytotoxic $\mathrm{T}$ cell activation, production of auto-antibodies, and complement activation ${ }^{(77)}$.

The first association between Zika virus infection and GBS was reported in French Polynesia in $2013^{(76)}$ in a woman who had fever, rash, and conjunctivitis 7 days before hospitalization when diffuse demyelinating disorder was confirmed. Viral antigens were not detected but neutralizing antibodies [immunoglobulin $\mathrm{M}(\operatorname{IgM})$ and immunoglobulin $\mathrm{G}(\operatorname{IgG})]$ against dengue and Zika viruses were present which can be one of the causes of this syndrome ${ }^{(78)}$.

An increase in GBS incidence was observed as the Polynesian Zika virus infection outbreak progressed, with an estimated incidence of 0.24 cases/1,000 infections. The majority of patients were male (74\%), aged 36-56 years, with rapidly progressing neurological symptoms starting at day 6 . Anti-Zika virus $\operatorname{IgM}$ or $\mathrm{IgG}$ and neutralizing antibodies against Zika virus were detected in $98 \%$ and $100 \%$ of patients, respectively. None of the GBS patients had Zika virus RNA detected by reverse transcription polymerase chain reaction (RT-PCR), emphasizing not only the short viremic period of infection but also the autoimmune nature of $\mathrm{GBS}^{(79)}{ }^{(80)}$.

In July 2015, only 4 months after confirmation of Zika virus circulation in Brazil, GBS diagnosis was confirmed in $42(55 \%)$ from 76 patients in Bahia State, with 26 (62\%) patients declaring to have had experienced the symptoms of Zika virus infection ${ }^{(81)}$. According to $\mathrm{WHO}^{(81)}$, by the end of March 2016, increased GBS incidence was reported in 13 countries with Zika virus circulation. In Brazil, 1,708 cases were reported from January to November 2015 with the most pronounced increases in incidence being reported in Alagoas (516.7\%), Bahia (196.1\%), Rio Grande do Norte (108.7\%), Piauí (108.3\%), Espírito Santo (78.6\%), and Rio de Janeiro (60.9\%). Zika virus infection has not been laboratory-confirmed for an overwhelming majority of Latin American cases, and it must be remembered that many of these countries are experiencing simultaneous circulation of

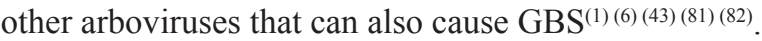

Further, transverse myelitis was reported in a Mexican teenager 9 days after the onset of Zika virus infection symptoms, presenting many signs of spinal damage ${ }^{(83)}$. Similar observations were made in dengue fever patients in Brazil ${ }^{(84)(85)(86)}$. High copy number of Zika virus RNA was detected in the urine, serum, and cerebrospinal fluid of the Mexican subject. Raised leukocyte and polymorphonuclear cell counts were also reported, indicating immune activation. Other microbial causes of myelitis were $\operatorname{absent}^{(83)}$.

Meningoencephalitis is yet another neurological complication of Zika virus infection, leading to hemiplegia, paresis, Babinski sign, ischemic foci, hypersensitivity of rolandic fissure, narrowing of the right callosomarginal artery, coma, spatial delusions with visual and kinesthetic hallucinations, and muscular weakness. Laboratory findings were the same as described ${ }^{(87)}$ for Zika virusassociated transverse myelitis. Other neurological consequences of Zika virus infection in the adult include a decline in bilateral acuity in hearing, transient dull or metallic hearing, and a delay between the emission and perception of sound. All these symptoms disappear after 10 days $^{(13)}$.

\section{CONCLUSIONS}

The spread of Zika virus in Brazil and other countries in the Americas has become a Public Health Emergency of International Concern. Long persistence of the virus in the neural 
cells of fetuses whose mothers are infected during pregnancy favors neural progenitor cell infection, reprogramming of genetic expression, and cell death, leading to microcephaly with viral and immune involvement. The precise mechanisms of this neuropathogenesis are still under study to elucidate why the Zika virus strain that is circulating in Brazil has this unprecedented destructive potential of the fetal central nervous system.

In conclusion, even though we are far from understanding the molecular mechanisms underlying Zika virus pathogenesis, there has been an undeniable progress in our understanding of these infections. All aspects of Zika virus biology merit further investigation. Areas that we still know relatively little about, with a high possible curative potential, are the detailed mechanisms of viral transfer through the placenta, protective immunological responses in mothers and fetuses and safe antiviral compounds. Before these fundamentals are built, we must improve our strategies of vector control and increase people's awareness of this disease.

\section{Conflict of Interest}

The authors declare to have no conflict of interest.

\section{REFERENCES}

1. Campos GS, Bandeira AC, Sardi SI. Zika virus outbreak, Bahia, Brazil. Emerg Infect Dis 2015; 21:1885-1886.

2. Zanluca C, De Melo VCA, Mosimann ALP, dos Santos GIV, dos Santos CND, Luz K. First report of autochthonous transmission of Zika virus in Brazil. Mem Inst Oswaldo Cruz 2015; 110:569-572.

3. Musso D. Zika virus transmission from French Polynesia to Brazil. Emerg Infect Dis 2016; 21:1887.

4. Zammarchi L, Tappe D, Fortuna C, Remoli ME, Gunther S, Venturi $\mathrm{G}$, et al. Zika virus infection in a traveller returning to Europe from Brazil, March 2015. Euro Surveill 2015; 20:1-3.

5. Ministério da Saúde. Brasil. Secretaria de Vigilância em Saúde. Departamento de Vigilância das Doenças Transmissíveis. Monitoramento dos casos de dengue, febre de chikungunya e febre pelo vírus Zika até a Semana Epidemiológica 45, 2015. Bol Epidemiológico 2015; 46:1-9.

6. Fauci AS, Morens DM. Zika Virus in the Americas - Yet Another Arbovirus Threat. N Engl J Med 2016; 363:1-3.

7. Pan American Health Organization (PAHO). Epidemiological Alert Zika virus infection [Internet]. Epidemiological Alert Zika virus infection. 2015 [cited 2015 May 7]. Available from: http:// www.paho.org/hq/index.php?option $=$ com_docman\&task $=$ doc_vie w\&Itemid $=270 \&$ gid $=30078 \&$ lang $=$ en

8. Henry R. Zika virus. Emerg Infect Dis 2014; 20:1090.

9. Duffy M, Chen T, Hancock T, Powers A, Kool J, Lanciotti R, et al. Zika Virus Outbreak on Yap Island, Federated States of Micronesia. N Engl J Med 2009; 360:2536-2543.

10. Cao-Lormeau VM. RE: Zika virus, French Polynesia, South Pacific, 2013. Emerg Infect Dis 2014; 20:1085-1086.

11. Musso D, Nhan T-X. Emergence of Zika Virus [Internet]. Vol. 04, Clinical Microbiology: Open Access. 2015. p. doi:10.4172/23275073.1000222. Available from: http://www.esciencecentral.org/ journals/emergence-of-zika-virus-2327-5073-1000222.php?aid= 61298
12. Musso D, Nilles EJ, Cao-Lormeau VM. Rapid spread of emerging Zika virus in the Pacific area. Clin Microbiol Infect 2014; 20:0595-596.

13. Tappe D, Nachtigall S, Kapaun A, Schnitzler P, Gunther S, SchmidtChanasit J. Acute Zika virus infection after travel to Malaysian Borneo, September 2014. Emerg Infect Dis 2015; 21:911-913.

14. Waehre T, Magaard A TD. Zika Virus Infection after Travel to Tahiti , December 2013. Emerg Infect Dis J 2014; 20:1412-1413.

15. Kutsuna S, Kato Y, Takasaki T, Moi M, Kotaki A, Uemura H, et al. Two cases of Zika fever imported from French Polynesia to Japan, December to January 2013 [Internet]. Vol. 19, Eurosurveill. 2014. p. 20683. Available from: http://www.eurosurveillance.org/ ViewArticle.aspx?ArticleId=20694

16. Fonseca K, Meatherall B, Zarra D, Drebot M, MacDonald J, Pabbaraju $\mathrm{K}$, et al. Case report: First case of Zika virus infection in a returning Canadian traveler. Am J Trop Med Hyg 2014; 91:1035-1038.

17. Pyke AT, Daly MT, Cameron JN, Moore PR, Taylor CT, Hewitson GR, et al. Imported Zika Virus Infection from the Cook Islands into Australia, 2014 [Internet]. PLoS Currents. 2014. Available from: http://currents.plos.org/outbreaks/?p=38348

18. Tappe D, Rissland J, Gabriel M, Emmerich P, Günther S, Held G, et al. First case of laboratory-confirmed Zika virus infection imported into Europe, November 2013. Euro Surveill 2014; 19:20685.

19. Ministério da Saúde. Brasil. Secretaria de Vigilância em Saúde. Monitoramento dos casos de dengue, febre de chikungunya e febre pelo vírus Zika até a Semana Epidemiológica 8, 2016 [Internet]. Vol. 47, Boletim Epidemiológico. 2016 [cited 2016 Apr 7]. Available from: http://portalsaude.saude.gov.br/images/pdf/2016/ janeiro/11/2015-053-para-substituir-na-p--gina.pdf

20. Sips GJ, Wilschut J, Smit JM. Neuroinvasive flavivirus infections. Rev Med Virol 2012; 22:69-87.

21. World Health Organization (WHO). Zika virus microcephaly and Guillain-Barré syndrome-Situation report 31 March 2016 [Internet]. 2016. p. 1-13. Available from: http://apps.who.int/iris/ bitstream/10665/204718/1/zikasitrep_31Mar2016_eng.pdf?ua=1

22. Ministério da Saúde. Brasil. Instituto Evandro Chagas (IEC) comprova relação do Vírus Zika com a Microcefalia e diagnostica os primeiros óbitos relacionados ao vírus [Internet]. 2015 [cited 2016 Mar 13]. Available from: http://www.iec.gov.br/index.php/ destaque/index/762

23. Ministério da Saúde. Brasil. Secretaria de Vigilância em Saúde.Centro de Operações de Emergências em Saúde Pública sobre Microcefalias. Informe Epidemiológico no 25 - Semana Epidemiológica (SE) 18/2016 (01/05 a 07/05/2016) Monitoramento dos casos de microcefalia no Brasil. [Internet]. [cited 2016 May 13]. Available from: http://combateAedes.saude.gov.br/images/sala-desituacao/informe_microcefalia_epidemiologico25.pdf

24. Cauchemez S, Besnard M, Bompard P, Dub T, Guillemette-Artur $\mathrm{P}$, Eyrolle-Guignot D, et al. Association between Zika virus and microcephaly in French Polynesia, 2013 - 15: a retrospective study. Lancet 2016; 6736:1-8.

25. Lanciotti RS, Kosoy OL, Laven JJ, Velez JO, Lambert AJ, Johnson AJ, et al. Genetic and serologic properties of Zika virus associated with an epidemic, Yap State, Micronesia, 2007. Emerg Infect Dis 2008; 14:1232-1239.

26. Blázquez AB, Escribano-Romero E, Merino-Ramos T, Saiz JC, Martín-Acebes MA. Stress responses in flavivirus-infected cells: Activation of unfolded protein response and autophagy. Front Microbiol 2014; 5:1-7.

27. Leis AA, Stokic DS. Neuromuscular Manifestations of West Nile Virus Infection. Front Neurol 2012; 3:1-10. 
28. Medeiros DBA, Nunes MRT, Vasconcelos PFC, Chang GJJ, Kuno G. Complete genome characterization of Rocio virus (Flavivirus: Flaviviridae), a Brazilian flavivirus isolated from a fatal case of encephalitis during an epidemic in São Paulo state. J Gen Virol 2007; 88:2237-2246.

29. Sirohi D, Chen Z, Sun L, Klose T, Pierson TC, Rossmann MG, et al. The 3.8 A resolution cryo-EM structure of Zika virus. Science 2016; 5316:1-7.

30. Mlakar J, Korva M, Tul N, Popović M, Poljšak-Prijatelj M, Mraz J, et al. Zika virus associated with microcephaly. N Engl J Med 2016; 374:951-958.

31. Perera-Lecoin M, Meertens L, Carnec X, Amara A. Flavivirus entry receptors: An update. Viruses 2013; 6:69-88.

32. Beasley DWC, Whiteman MC, Zhang S, Huang CY, Schneider BS, Smith DR, et al. Envelope protein glycosylation status influences mouse neuroinvasion phenotype of genetic lineage 1 West Nile virus strains. J Virol 2005; 79:8339-8347.

33. Haddow AD, Schuh AJ, Yasuda CY, Kasper MR, Heang V, Huy $\mathrm{R}$, et al. Genetic characterization of zika virus strains: Geographic expansion of the asian lineage. PLoS Neg1 Trop Dis 2012; 6:e1477.

34. Faye O, Freire CCM, Iamarino A, Faye O, de Oliveira JVC, Diallo $\mathrm{M}$, et al. Molecular evolution of zika virus during its emergence in the $20^{\text {th }}$ Century. PLoS Negl Trop Dis 2014; 8:e2636.

35. Piorkowski G, Richard P, Baronti C, Gallian P, Charrel R, LeparcGoffart I, et al. Complete coding sequence of Zika virus from Martinique Outbreak in 2015. Genome Announc 2016; 2:e00500-514.

36. Calvet G, Aguiar RS, Melo AS, Sampaio SA, de Filippis I, Fabri A, et al. Detection and sequencing of Zika virus from amniotic fluid of fetuses with microcephaly in Brazil: a case study. Lancet Infect Dis 2016; 16:653-660.

37. Driggers RW, Ho C-Y, Korhonen EM, Kuivanen S, Jääskeläinen AJ, Smura T, et al. Zika Virus infection with prolonged maternal viremia and fetal brain abnormalities. N Engl J Med 2016; 374 : 2142-2151

38. Garcez PP, Correia Loiola E, Madeiro da Costa R, Higa LM, Trindade P, Delvecchio R, et al. Zika virus impairs growth in human neurospheres and brain organoids. Science 2016; 352:816-818.

39. Roth A, Mercier A, Lepers C, Hoy D, Duituturaga S, Benyon E, et al. Concurrent outbreaks of dengue, chikungunya and Zika virus infections - an unprecedented epidemic wave of mosquito-borne viruses in the Pacific 2012-2014. Euro Surveill 2014; 19:20929.

40. Diallo D, Sall AA, Diagne CT, Faye O, Faye O, Ba Y, et al. Zika virus emergence in mosquitoes in Southeastern Senegal, 2011. PLoS One 2014; 9:4-11.

41. Marcondes CB, Ximenes MF. Zika virus in Brazil and the danger of infestation by Aedes (Stegomyia) mosquitoes. Rev Soc Bras Med Trop 2015; 49:4-10.

42. Diagne CT, Diallo D, Faye O, Ba Y, Faye O, Gaye A, et al. Potential of selected Senegalese Aedes spp. mosquitoes (Diptera: Culicidae) to transmit Zika virus. BMC Infect Dis 2015; 15:492.

43. Ledermann JP, Guillaumot L, Yug L, Saweyog SC, Tided M, Machieng P, et al. Aedes hensilli as a potential vector of chikungunya and zika viruses. PLoS Negl Trop Dis 2014; 8:e3188.

44. Bonaldo MC, Ribeiro IP, Lima NS, Santos AAC, Menezes LSR, Cruz SOD, et al. Isolation of infective Zika virus from urine and saliva of patients in Brazil. bioRxiv 2016; p. 045443. doi: http:// dx.doi.org/10.1101/045443.

45. Leung GHY, Baird RW, Druce J, Anstey NM. Zika virus infection in Australia following a monkey bite in Indonesia. Southeast Asian J Trop Med Public Health 2015; 46:460-464.
46. Zeinad AK. Vírus do Nilo Ocidental - Nova ameaça à segurança transfusional ? Rev Bras Hematol Hemoter 2004; 26:114-121.

47. Gould E, Solomon T. Pathogenic flaviviruses. Lancet 2008; 371:500-509.

48. Petersen E, Wilson ME, Touch S, McCloskey B, Mwaba P, Bates M, et al. Unexpected and Rapid Spread of Zika Virus in The Americas - Implications for Public Health Preparedness for Mass Gatherings at the 2016 Brazil Olympic Games. Int J Infect Dis 2016; 44:11-15.

49. Dupont-Rouzeyrol M, O'Connor $\mathrm{O}$, Calvez E, Daurès M, John M, Grangeon J-P, et al. Co-infection with Zika and Dengue Viruses in 2 Patients, New Caledonia, 2014. Emerg Infect Dis 2015; 21:381-382.

50. Musso D, Nhan T, Robin E, Roche C, Bierlaire D, Zisou K, et al. Potential for Zika virus transmission through blood transfusion demonstrated during an outbreak in French Polynesia, November 2013 to February 2014. Euro Surveill 2014; 19:14-16.

51. Vasconcelos PFDC. Doença pelo vírus Zika: um novo problema emergente nas Américas? Rev Pan-Amazônica Saúde 2015; 6:9-10.

52. Ministério da Saúde. Brasil. Agência Nacional de Vigilância (ANVISA). Nota Técnica Conjunta no. 001/2015 CGSH/GGPBS/ GGMON. Critérios técnicos para gerenciamento do risco sanitário no uso de hemocomponentes em procedimentos transfusionais frente à situação de Emergência em Saúde Pública de Importância Nacional por casos de infecção por Vírus Zika no Brasil. [Internet]. 2015 [cited 2016 Mar 13]. p. 1-7. Available from: http://www.saude. ba.gov.br/novoportal/images/stories/

53. Musso D, Richard V, Broult J, Cao-Lormeau VM. Inactivation of dengue virus in plasma with amotosalen and ultraviolet $\mathrm{A}$ illumination. Transfusion 2014; 54:2924-2930.

54. Foy BD, Kobylinski KC, Foy JLC, Blitvich BJ, da Rosa AT, Haddow AD, et al. Probable Non-Vector-borne Transmission of Zika Virus, Colorado, USA. Emerg Infect Dis 2011; 17:880-882.

55. Musso D, Roche C, Robin E, Nhan T, Teissier A, Cao-Lormeau VM. Potential sexual transmission of Zika virus. Emerg Infect Dis 2015; 21:359-361.

56. Mansuy JM, Dutertre M, Mengelle C, Fourcade C, Marchou B, Delobel P, et al. Zika virus: high infectious viral load in semen, a new sexually transmitted pathogen? Lancet Infect Dis 2016; 16:405.

57. Atkinson B, Hearn P, Afrough B, Lumley S, Carter D, Aarons EJ, et al. Detection of Zika virus in semen. Emerg Infect Dis 2016; 22:940.

58. Heymann DL, Hodgson A, Sall AA, Freedman DO, Staples JE, Althabe F, et al. Zika virus and microcephaly: why is this situation a PHEIC? Lancet 2016; 6736:1-3.

59. Besnard M, Lastère S, Teissier A, Cao-Lormeau VM, Musso D. Evidence of perinatal transmission of Zika virus, French Polynesia, December 2013 and February 2014. Euro Surveill 2014; 19:pii=20751.

60. Dupont-Rouzeyrol M, Biron A, O’Connor O, Huguon E, Descloux E. Infectious Zika viral particles in breastmilk. Lancet 2016; 387:1051

61. Noronha L, Zanluca C, Azevedo MLV, Luz KG, Santos CND. Zika virus damages the human placental barrier and presents marked fetal neurotropism. Mem Inst Oswaldo Cruz 2016; 111:287-293.

62. Alves JAG, Câmara LMC, Costa FS, Rocha RS, Araújo MNT. Os macrófagos na placenta durante o trabalho de parto. Rev Bras Ginecol e Obs 2009; 31:89-93.

63. Tang Z, Abrahams VM, Mor G, Guller S. Placental Hofbauer cells and complications of pregnancy. Ann N Y Acad Sci 2011; 1221:103-108. 
64. Martines RB, Bhatnagar J, Keating MK, Flannery LS, Muehlenbachs A, Gary J, et al. Notes from the Field: evidence of Zika virus infection in brain and placental tissues from two congenitally infected newborns and two fetal losses - Brazil, 2015. MMWR Morb Mortal Wkly Rep 2016; 65:159-160.

65. Wang H, Liang G. Epidemiology of Japanese encephalitis: past, present, and future prospects. Ther Clin Risk Manag 2015; 11: 435-438.

66. Rodrigues LC. Zika: the tragedy and the opportunities. Am J Public Health 2016; 106:582.

67. World Health Organization (WHO). Assessment of infants with microcephaly in the context of Zika virus. 2016. p. 1-2. [Internet]; Available from: http://apps.who.int/iris/bitstream/10665/204475/1/ WHO_ZIKV_MOC_16.3_eng.pdf?ua $=1$

68. Sarno M, Sacramento GA, Khouri R, do Rosário MS, Costa F, Archanjo G, et al. Zika virus infection and stillbirths: a case of hydrops fetalis, hydranencephaly and fetal demise. PLoS Negl Trop Dis 2016; 10:e0004517.

69. Schuler-Faccini L, Ribeiro EM, Feitosa IML, Horovitz DDG, Cavalcanti DP, Pessoa A, et al. Possible association between Zika virus infection and microcephaly - Brazil, 2015. MMWR Morb Mortal Wkly Rep 2016; 65:59-62.

70. Besnard M, Eyrolle-Guignot D, Guillemette-Artur P, Lastère S, Bost-Bezeaud F, Marcelis L, et al. Congenital cerebral malformations and dysfunction in fetuses and newborns following the 2013 to 2014 Zika virus epidemic in French Polynesia. Euro surveillance 2016; 21:30181.

71. Freitas BP, Dias JRO, Prazeres J, Sacramento GA, Ko AI, Maia $\mathrm{M}$, et al. Ocular findings in infants with microcephaly associated with presumed Zika virus congenital infection in Salvador, Brazil. JAMA Ophthalmol 2016; 134:529-535.

72. Ventura CV, Maia M, Ventura BV, Van Der Linden V, Araújo $\mathrm{EB}$, Ramos RC, et al. Ophthalmological findings in infants with microcephaly and presumable intra-uterus Zika virus infection. Arq Bras Oftalmol 2016; 79:1-3.

73. Adibi JJ, Marques ETA, Cartus A, Beigi RH. Teratogenic effects of the Zika virus and the role of the placenta. Lancet 2016; 6736:1-4.

74. Garcez PP, Nascimento J, Vasconcelos JM, Costa RM, Delvecchio R, Trindade $\mathrm{P}$, et al. Combined proteome and transcriptome analyses reveal that Zika virus circulating in Brazil alters cell cycle and neurogenic programmes in human neurospheres. 2016 [Internet]. cited; May 9, 2016 Available from: https://doi.org/10.7287/peerj.preprints.2033v1.
75. Lebrun G, Chadda K, Reboux AH, Martinet O, Gauzère BA. Guillain-Barré syndrome after chikungunya infection. Emerg Infect Dis 2009; 15:495-496.

76. Oehler E, Watrin L, Larre P, Leparc-Goffart I, Lastere S, Valour F, et al. Zika virus infection complicated by Guillain-Barré syndrome--case report, French Polynesia, December 2013. Euro Surveill 2014; 19:7-9.

77. Nyati KK, Prasad KN. Role of cytokines and toll-like receptors in the immunopathogenesis of Guillain-Barré syndrome. Mediators Inflamm 2014; 2014:1-10. Article ID 758639.

78. Koga M, Gilbert M, Li J, Yuki N. Complex of GM1- and GDlalike lipo-oligosaccharide mimics GM1b, inducing anti-GM1b antibodies. PLoS One 2015; 10:e124004.

79. Malkki H. CNS infections: Zika virus infection could trigger Guillain-Barré syndrome. Nat Rev Neurol 2016; 12:187.

80. Cao-Lormeau V-M, Blake A, Mons S, Lastère S, Roche C, Vanhomwegen J, et al. Guillain-Barré Syndrome outbreak associated with Zika virus infection in French Polynesia: a casecontrol study. Lancet 2016; 387:1531-1539.

81. World Health Organization (WHO). Zika virus microcephaly and Guillain-Barré syndrome [Internet]. Vol. 2016. 2016. p. 1-13. Available from: http://who.int/emergencies/zika-virus/strategicresponse-framework.pdf?ua=1

82. Ribeiro GS, Kitron U. Zika virus pandemic: a human and public health crisis. Rev Soc Bras Med Trop 2016; 49:1-3.

83. Mécharles S, Herrmann C, Poullain P, Tran T, Deschamps N, Mathon $\mathrm{G}$, et al. Case report acute myelitis due to Zika virus infection. Lancet 2016; 8:6736.

84. Brito CAA, Sobreira S, Cordeiro MT, Lucena-Silva N. Acute disseminated encephalomyelitis in classic dengue. Rev Soc Bras Med Trop 2007; 40:236-238.

85. Oliveira DB, Machado G, Almeida GMF, Ferreira PCP, Bonjardim $\mathrm{CA}$, Trindade GS, et al. Infection of the central nervous system with dengue virus 3 genotype I causing neurological manifestations in Brazil. Rev Soc Bras Med Trop 2016; 49:125-129.

86. Sousa AM, Alvarenga MP, Alvarenga RMP. A cluster of transverse myelitis following dengue virus infection in the Brazilian Amazon Region. Trop Med Health 2014; 42:115-120.

87. Carteaux G, Maquart M, Bedet A, Contou D, Brugières P, Fourati $\mathrm{S}$, et al. Zika virus associated with meningoencephalitis. N Engl J Med 2016; 374:1595-1596. 